\title{
Effect of Chromium Supplementation on Physiological Parameters in Local Buffaloes during Different Seasons
}

\author{
Kawardeep Kour*, Jonali Devi, Aditi Lal Koul, D. Chakraborty and \\ Mandeep Singh Azad
}

Division of Veterinary Physiology and Biochemistry, Faculty of Veterinary Sciences and Animal Husbandry, SKUAST-J, RS Pura, Jammu181102, Jammu and Kashmir, India

*Corresponding author

\section{A B S T R A C T}

The work was aimed to study the effect of chromium propionate supplementation on physiological parameters in buffaloes during summer, autumn \& winter seasons. Eighteen numbers of lactating buffaloes were selected and divided into three groups viz., Control,

\begin{tabular}{|l|}
\hline Ke y w or d s \\
Buffalo, Chromium \\
propionate, \\
$\begin{array}{l}\text { Seasons, Lactation, } \\
\text { Physiological } \\
\text { parameters }\end{array}$ \\
\hline Article Info \\
\hline $\begin{array}{l}\text { Accepted: } \\
\text { 10 June } 2019 \\
\text { Available Online: } \\
\text { 10 July } 2019\end{array}$ \\
\hline \hline
\end{tabular}
Treatment -1 (T-1) \& Treatment-2 (T-2). Treatment-1 and Treatment-2 were supplemented with $9 \mathrm{mg} \& 18 \mathrm{mg}$ Chromium propionate/head/day respectively in each season; whereas, control group was not given chromium supplementation. Physiological parameters like rectal temperature, pulse rate and respiration rate were assessed weekly. It was observed that chromium propionate supplementation significantly lowered $(\mathrm{P}<0.05)$ pulse rate and respiration rate in treatment groups during summer and winter season; whereas, rectal temperature did not vary significantly between control and chromium supplemented groups. Among different seasons significantly lower winter values were observed in comparison to summer and autumn seasons in control and T2 group. Season had significant effect $(\mathrm{P}<0.05)$ on respiration rate in all the group, where the summer value was significantly higher $(\mathrm{P}<0.05)$ in comparison to autumn which were significantly higher $(\mathrm{P}<0.05)$ to winter values. Pulse rate too was significantly higher $(\mathrm{P}<0.05)$ in summer in comparison to winter and autumn season in all groups. The rectal temperature did not show any significant variation among different groups during different seasons. Based on the study, it can be concluded that chromium supplementation has ameliorative effect on physiological parameters during heat and cold environmental stress conditions in lactating buffaloes.

\section{Introduction}

Animal undergo various kinds of stress such as physical, nutritional, chemical, psychological and environmental. Stress is a condition which arises when an animal suddenly faces a change in its environment (Kumar et al., 2011). Buffaloes being a seasonal breeder show signs of great physical distress when exposed to environmental stress as compared to other farm animals (Das et al., 1999). This is due to fact that their body absorbs a great deal of solar radiation because of their dark skin and spars coat or hair. Increased environmental temperature augments the efforts of the animals to 
dissipate body heat, resulting in increased respiration rate, body temperature, heart beat and water consumption causing redistribution in blood flow and changes in endocrine functions that negatively effect the productivity. During the lactation period, there is a dramatic increase in energy requirements needed for the onset of lactation and to meet their energy demand, the animal lipolysis its body reserves which is reflected by elevated levels of non esteric fatty acid (NEFA), $\beta$ hydroxy butyric acid (BHBA) and decreased body condition score

Chromium (Cr) an essential trace mineral (Anderson, 1987) has been found to that alleviates stress-associated effects (Garg and Bansal 2000). Supplementation of $\mathrm{Cr}$ has shown to improve performance of growing and lactating ruminants exposed to thermal stress (Kumar et al., 2013b) Chromium is also an essential component to enzyme function that supports the conversion of $\mathrm{T}_{4}$ to triiodothyronine. Its supplementation improves immune functions by enhancing immunoglobulin production, antibody titers to antigen or by reducing cortisol concentration and modulating inflammatory responses (Weiss and Spears, 2005). Our research was based to evaluate the beneficial effect of chromium supplementation during different seasons in order to coup up the thermal (heat and cold) stress in lactating buffaloes of the region.

\section{Materials and Methods}

The study was conducted on $18 \mathrm{~s}$ adult buffaloes of a private dairy farm in Jammu during their $3^{\text {rd }}$ lactation. All animals were fed green fodder (depending upon availability) and concentrates were fed as per managemental practices being followed by the dairy owner. The animals selected were checked for their normal health, productive and reproductive history. The study was conducted in three seasons, i.e. summer $\left(1^{\text {st }}\right.$ June to $31^{\text {st }}$ August) autumn $\left(1^{\text {st }}\right.$ September to $31^{\text {st }}$ November) and winter $\left(1^{\text {st }}\right.$ December to $2^{\text {nd }}$ March animals were divided into three groups : Control group: - The animals were not given chromium supplementation: Treatment-1 (T1): - Animals in this group were supplemented with chromium propionate @ $9 \mathrm{mg} / \mathrm{head} /$ day during study period: Treatment-2 (T2): - Animals in this group were supplemented with chromium propionate @ $18 \mathrm{mg} / \mathrm{head} /$ day during study period. Physiological variables like pulse rate, respiration rate and rectal temperature of each animals were measured and recorded weekly in all seasons. Respiration rate was determined by observing the flank movement on lower part of abdomen from a distance without disturbing the animal. The reading was expressed as breath per minute (bpm). Pulse rate was measured by placing the sensitive part of index finger on coccygeal artery located at the ventral surface of tail head. The pulse rate was recorded for one minute and expressed in number of beats per minute. The rectal temperature was recorded with the help of clinical thermometer by placing it on the mucus membrane of rectum. It was expressed in degree Celsius $\left({ }^{\circ} \mathrm{C}\right)$. For all the observed data, the standard statistical procedures recommended by Snedecor and Cochran (2004) have been followed. The data were presented by showing mean and standard error. The significant differences of values for different parameters studied were assessed by the test of one way and two-way analysis of variance depending upon the data. All the above calculations were carried out using SPSS software version 16.0.

\section{Results and Discussion}

\section{Respiration rate and pulse rate}

Table 1 depicted respiration and pulse rate in control and chromium supplemented lactating 
buffaloes during summer, autumn and winter seasons. During summer season, these parameters were found significantly higher $(\mathrm{P}<0.05)$ in control group as compared to chromium supplemented groups; however, in autumn and winter seasons these parameters did not vary significantly between different groups. Therefore, the study revealed that chromium supplementation had influence on these parameters by decreased the increasing rate of respiration and pulse rate in summer season. Similar results have been reported by Yari et al., (2010), who reported lower respiration rate in $1.0 \mathrm{ppm} \mathrm{Cr}$ supplemented calves exposed to high ambient temperature $\left(42^{\circ} \mathrm{C}\right)$. An-Qiang et al., (2009) studied the effect of chromium picolinate supplementation on respiration rates in Holstein cows and reported a slight difference in the degree of response of control group cows that showed a greater elevation of respiration rates as well as rectal temperatures than the supplemented ones. In contrary to our result, Kim et al., 2009 in pig; Mirzaei et al., 2011 in cows and Ghorbani et al., 2012 in Holestein calves reported that chromium supplementation caused elevation in respiration rate, which was significantly higher in the chromium treated groups compared with the control groups. However, others works (Kumar et al., 2013 in buffalo calves and Zhang et al., 2014 in lactating cows) reported that there was no difference in respiration and pulse rate between control and $\mathrm{Cr}$ supplemented group.

The changes in the respiration rate are an adaptive response of the animal to maintain homoeothermic balance. In domestic animals, respiration rate increases due to the activation of thermo-receptors in the skin when they are exposed to higher ambient temperature. Such activation of the receptors, in turn, sends neural signals to the hypothalamus that increases respiratory activity to accelerate heat loss from the body by respiratory evaporation (Haidary and Ahmed, 2004). The increase in pulse rate causes an increase in the blood flow to the surface and thereby facilitates heat loss (Marai et al., 2007). Table 1 depicted the respiration and pulse rate in lactating buffaloes in different seasons. When comparing different seasons, significantly higher $(\mathrm{P}<0.05)$ respiration and pulse rate were observed in summer in comparison to autumn and winter seasons in all groups. The increase in THI, which ranged between 85.38 to 86.87 in summer months (Table 1) had a direct influence on respiration and pulse rate, as when THI exceeded a certain threshold level, the homeostasis mechanism failed and animal's body responded with higher respiration rate. Previous studies also reported that respiration and pulse rate significantly increased in animals exposed to high thermal temperature in buffaloes (Gurdev et al., 2007 ; Lallawmikimi et al., 2012; Singh et al., 2014), cows (Robinson et al.,1987; Bouraoui et al., 2002) and in goat and sheep (Maurya et al., 2007, Al-Samawi et al., 2014) ; whereas, Dandage (2009) reported that there is increased respiration rate in the extreme seasons (winter and summer) of the year on Sahiwal, Karan Fries and Murrah buffaloes. Padilla et al., (2006) reported a higher respiration rate of 71.5 /minute during summer compared to $38.8 /$ minute during winter in lactating cows; they also depicted that the increasing trend in pulse rate continued even when the ambient temperature declined indicating that the physiological responses of animals returned to its normal levels only after a definite period when animals were brought to comfort zone.

Perez (2000) observed that there was a significant increase in respiration rate (RR) with an increase in ambient temperature and the relative humidity in hot dry season and hot humid season, respectively. Increase in RR indicates that the animals were under heat stress and increase in RR is to facilitate heat loss during heat stress. 
Table.1 Effect of chromium supplementation in different doses during different seasons on some physiological parameters in local buffaloes

\begin{tabular}{|c|c|c|c|}
\hline \multicolumn{5}{|c|}{ RESPIRATION RATE (per minute) } \\
\hline Groups & Summer & Autumn & Winter \\
\hline Control & $41.11^{\mathrm{cy}} \pm 0.58$ & $32.55^{\mathrm{b}} \pm 0.68$ & $27.44^{\mathrm{a}} \pm 0.92$ \\
\hline Treatment 1 & $40.00^{\mathrm{cy}} \pm 1.24$ & $34.22^{\mathrm{b}} \pm 0.70$ & $26.66^{\mathrm{a}} \pm 0.96$ \\
\hline Treatment 2 & $37.33^{\mathrm{cx}} \pm 1.33$ & $34.66^{\mathrm{b}} \pm 0.81$ & $25.88^{\mathrm{a}} \pm 0.93$ \\
\hline & PULSE RATE (per minute) $^{\circ}$ & \\
\hline Control & $83.77^{\mathrm{by}} \pm 0.90$ & $72.44^{\mathrm{a}} \pm 2.04$ & $71.44^{\mathrm{a}} \pm 0.76$ \\
\hline Treatment 1 & $80.00^{\mathrm{bx}} \pm 0.81$ & $72.22^{\mathrm{a}} \pm 2.01$ & $74.44^{\mathrm{a}} \pm 0.86$ \\
\hline Treatment 2 & $78.44^{\mathrm{bx}} \pm 1.28$ & $72.66^{\mathrm{a}} \pm 1.52$ & $71.44^{\mathrm{a}} \pm 0.89$ \\
\hline Control & ${\text { RECTAL TEMPERATURE }\left({ }^{\circ} \mathbf{F}\right)}$ \\
\hline Treatment 1 & $100.7 \pm 0.33$ & $100.7 \pm 0.08$ & $100.4 \pm 0.28$ \\
\hline Treatment 2 & $100.4 \pm 0.30$ & $100.3 \pm 0.28$ & $100.1 \pm 0.63$ \\
\hline
\end{tabular}

*Means with different superscripts bearing a, b, c differ significantly $(\mathrm{P}<0.05)$ between seasons within groups.

${ }^{\#}$ Means with different superscripts bearing $\mathrm{x}, \mathrm{y}, \mathrm{z}$ differ significantly $(\mathrm{P}<0.05)$ between groups within seasons.

\section{Rectal temperature (RT)}

As presented in Table 1, rectal temperature did not vary significantly between control and chromium propionate supplemented groups in summer, autumn and winter seasons. Our results are in conjunction with results proposed by other workers (An-Qiang et al., 2009; Nikkhah et al., 2011; Kumar et al., 2013; Zhang et al., 2014) that dietary chromium supplementation did not have beneficial impact on rectal temperature in animals under stress conditions. The fact that increased respiration rate help in heat dissipation might be a cause to prevent the increase in rectal temperature in animals which is in conjunction to our result where there is increase in respiration rate but rectal temperature is not affected. Contrary to our results, Ghorbani et al., 2012 in pigs, Moonsie-Shageer and Mowat (2014) and Yari et al., 2010 in stressed calves reported decreased rectal temperature in $\mathrm{Cr}$ supplemented animals exposed to high ambient temperature. On the other hand, Kim et al., (2009) observed decreased rectal temperature in $\mathrm{Cr}$ supplemented pigs exposed to low ambient temperature $\left(13.8^{\circ} \mathrm{C}\right)$.

There was no significant difference found in rectal temperature between different seasons in control and treatment groups Gurdev et al., (2007) studied about physiological indices in buffaloes exposed to sun and reported a nonsignificant difference in rectal temperature in exposed and non-exposed animals. However, Koubkova et al., (2002) reported significant increase in rectal temperature from 37.3 to $39.3^{\circ} \mathrm{C}$, respiration rate from 28 to 81 per minute and pulse rate from 64 to 81 per min in high yielding Holstein cows, when exposed to high temperature exposure conditions.

\section{References}

Al-Haidary, A., Ahmed, A., 2004. Physiologic response of Niamey sheep to heat stress Physiological, hematological and 
biochemical alterations in heat stressed goats 61 challenge under semi-arid environment. International Journal Agricultural Biology. 2, 307-309.

Al-Samawi, K. A., Al-Hassan, M. J. and Swelum, A. A. 2014. Thermoregulation of female Aardi goats exposed to environmental heat stress in Saudi Arabia. Indian Journal of Animal Research, 48(4): 344-349.

Anderson, R. A. 1987. Chromium. In: Trace elements in human and animal nutrition. Edited by W. Mertz. Vol. 1. Academic Press, New York, pp 225-224.

An-Qiang, L., Zhi-Sheng, W. and An-Guo, Z. 2009. Effect of chromium picolinate supplementation on early lactation performance, rectal temperatures, respiration rates and plasma biochemical response of holstein cows under heat stress. Pakistan Journal of Nutrition, 8 (7): 940-945.

Bouraoui, R., Lahmar, M., Majdoub, A., Djemali, M.N. and Belyea, R. 2002. The relationship of temperature-humidity index with milk production of dairy cows in a Mediterranean climate. Animal Research 51(6) 479-491.

Dandage, S. D. 2009. Estimates of thermal load and heat exchange in cattle and buffaloes. M.V.Sc. Thesis submitted to NDRI Deemed University, Karnal (Haryana), India.

Das, S. K., Upadhyaya, R. C. and Madan, M. L. 1999. Heat stress in Murrah buffalo calves. Livestock Production Sciences, 61: 71-78.

Garg, M. C. and Bansal, D. D. 2000. Protective antioxidant effect of vitamins in streptozotocin induced stress in diabetic rats. Indian Journal of Experimental Biology, 38:101-104.

Ghorbani. A., Sadri, Alizadeh, A. R. and Bruckmaier R. M. 2012. Performance and metabolic responses of Holstein calves to supplemental chromium in colostrum and milk. Journal of Dairy science, 95(10): 5760-5769.
Gudev, D., Popova-Ralcheva, S., Moneva, P., Aleksiev, Y., Peeva, Tz., Penchev, P. and Ilieva, I. 2007. Physiological indices in buffaloes exposed to sum. Archiva Zootechnica, 10: 127-133.

Kim, B. G., Lindermann, M. D. and Cromwell, G. L. 2009. The effects of dietary chromium (III) picolinate on growth performance, blood measurements, and respiratory rate in pigs kept in high and low ambient temperature. Journal of Animal Science, 87(5): 1695-704.

Koubkova, M., Knizkova, I., Kunc, P., Hartlova, H., Flusser, J. and Dolezal, O. 2002. Influence of high environmental temperatures and evaporative cooling on some physiological, haematological and biochemical parameters in high-yielding dairy cows. Czech Journal of Animal Science, 47: 309-318.

Kumar, A., Singh, G., Kumar, B.V.S and Meur, S. K. 2011. Modulation of antioxidant status and lipid peroxidation in erythrocyte by dietary supplementation during heat stress in buffaloes. Livestock Science, 138: 299-30.

Kumar, M., Kaur, H., Tyagi, A. K., Kewalramani, N. J., Mani, V., Deka, R. S., Sharma, V. K., Chandra, G. and Dang, A. K. 2013a. Effect of feeding inorganic chromium on growth performance, endocrine variables, and energy metabolites in winter-exposed buffalo calves (Bubalus bubalis). Bi ological Trace Element Research, 155: 352-360.

Kumar, M., Kaur, H., Tyagi, A. K., Mani, V., Deka, R. S., Chandra, G. and Sharma, V. K. 2013 b. Assessment of chromium content of feedstuffs, their estimated requirement, and effects of dietary chromium supplementation on nutrient utilization, growth performance, and mineral balance in summer-exposed buffalo calves (Bubalusbubalis). Biological Trace Element Research, 155: 29-37.

Lallawmkimi, M.C. Singh, S.V., De, S., Hooda, O. K., Upadhyay, R.C., Singh, A.K and Vaidya M.M. 2012. HSP 72 expression 
and antioxidant enzymes in Murrah buffaloes during heat exposure in climatic chamber. Indian Journal of Animal Science. 82 (3): 268

Marai, I.F.M., El-Darawany, A.A., Fadiel, A., and Abdel-Hafez, M.A.M., (2007). Physiological traits as affected by heat stress in sheep- A review. Small Ruminant Research. 71: 1-12.

Maurya, V.P., Naqvi, S.M.K., Joshi, A. and Mittal, J.P. 2007.Effect of high temperature stress on physiological responses of Malpura Sheep. Indian Journal of Animal Science, 77: 1244-1247

Mirzaei, M. G., R. Ghorbani, M. Khorvash, H. R. Rahmani, and A. Nikkhah. 2011. Chromium improves production and alters metabolism of early lactation cows in summer. Journal of Animal Physiology and Animal Nutrition, 95:81-89.

Moonsie-Shageer, S. and Mowat, D. N. 1993. Effects of level of supplemental chromium on performance, serum constituents and immune status of stressed feeder calves. Journal of Animal Science, 71: 232-238.

Nikkhah, A., Mirzaei, M., Khorvash, M., Rahmani, H. R. and Ghorbani, G. R. 2011. Chromium improves production and alters metabolism of early lactation cows in summer. Journal of Animal Physiology and Animal Nutrition, 95: 8189.

Padilla, L., Matsui T, Kamiya, Y., Kamiya, M., Tanaka, M. 2006. Heat stress decreases plasma vitamin $\mathrm{C}$ concentration in lactating cows. Livestock Sciences, 101: 300-304.

Robinson, J. B., Ames, D.R., and Milliken, G. A. 1986. sHeat production of cattle acclimated to cold, thermoneutrality and heat when exposed to thermoneutrality and heat stress. Journal of Animal Science. 62: 1434-40.

Singh, S. V., Hooda, O. K., Narwade, B., Beenam and Upadhyay, R. C., 2014. Effect of cooling system on feed and water intake, body weight gain and physiological responses of Murrah buffaloes during summer conditions. Indian Journal of Dairy Science, 67 (5): 426-431.

Snedecor, G. W. and Cochran, W. G. 2004. Statistical methods $8^{\text {th }}$ edition oxford and IBJ pub. Co., Kolkata

Weiss, W. P. and Spears, J. W. 2005. Vitamin and trace mineral effects on immune function of ruminants. 10th International Symp. On Ruminant Physiology, Wageningen.

Yari, M., Nikkhah, A., Alikhani, M., Khorvash, M., Rahmani, H., and Ghorbani, G.R. 2010. Physiological calf responses to increased chromium supply in summer. Journal of Dairy Science, 93: 4111-4112.

Zhang, F. J., Weng, X. G., Wang, J. F., Zhou, D., Zhai, C. C., Hou, Y. X. and Zhu, Y. H. 2014. Effect of temperature-humidity index and chromium supplementation on antioxidant capacity, heat shock protein 72 and cytokine responses of lactating cows. Journal of Animal Sciences, 92: 3026-3034.

\section{How to cite this article:}

Kawardeep Kour, Jonali Devi, Aditi Lal Koul, D. Chakraborty and Mandeep Singh Azad. 2019. Effect of Chromium Supplementation on Physiological Parameters in Local Buffaloes during Different Seasons. Int.J.Curr.Microbiol.App.Sci. 8(07): 1178-1183. doi: https://doi.org/10.20546/ijcmas.2019.807.139 